\title{
Dociekania
}

\section{Żyd i Arab/muzułmanin w europejskich geometriach tożsamości i różnicy}

Monika Bobako

TEKSTY DRUGIE 2017, NR 2, S. 255-279

DOI: $10.18318 / \mathrm{td} .2017 .2 .15$

$\mathbf{N}$ arastającej siły uprzedzeń antyislamskich w Europie nie da się zrozumieć bez sięgnięcia do historii zachodniego antysemityzmu. Ten komparatystyczny i kontekstualizujący zabieg poznawczy pozwala bowiem, z jednej strony, dostrzec podobieństwo struktur i wyobrażeń, na których opierają się uprzedzenia wymierzone w żydów i muzułmanów ${ }^{1}$, z drugiej - umożliwia także

1 Dotyczy to głównie sposobów, na jakie grupy te konstruowane są jako niereformowalnie „obce” i zagrażających czystości europejskiej/ chrześcijańskiej tożsamości. W obu przypadkach owi „obcy” postrzegani są przez pryzmat zesencjalizowanych kategorii zbiorowych, określonych przez odniesienie do tożsamości religijnej, która w toku historii zostaje zredefiniowana jako tożsamość „etniczna”, "kulturowa”, "rasowa” lub „narodowa”. W obu przypadkach pojawiają się teorie spiskowe, sugerujące ukryte dążenia do zdominowania większościowego społeczeństwa i jego judaizację/islamizację. W obu przypadkach wróg jest definiowany przez wzajemnie wykluczające się cechy - jednocześnie słaby i zagrażający, biedny i bajecznie bogaty (żydowski bankier, arabski szejk), niecywilizowany i wyrafinowany etc. W obu przypadkach tłem uprzedzeń i rasizmu jest długa historia konfliktów w relacjach z chrześcijaństwem.
Tekst powstał w ramach projektu badawczego, który został sfinansowany ze środków Narodowego Centrum Nauki przyznanych na podstawie decyzji numer DEC-2011/03/B/ HS1/01693.

\section{Monika Bobako}

- doktor filozofii, absolwentka UAM oraz Uniwersytetu Środkowoeuropejskiego w Budapeszcie. Adiunkt w Pracowni Pytań Granicznych UAM w Poznaniu. Autorka książki Demokracja wobec różnicy. Multikulturalizm i feminizm w perspektywie polityki uznania (2010).W najbliższych miesiącach nakładem wydawnictwa Universitas ukaże się jej książka Islamofobia jako technologia władzy. Studium z antropologii politycznej. Kontakt: bomonako@gmail.com 
pokazanie, w jaki sposób fenomeny te - wzajemnie się warunkując - współuczestniczyły na przestrzeni wieków w kształtowaniu autodefnicji chrześcijańskiej (a potem także sekularyzującej się) Europy.

Inspirację do takich rozważań można znaleźć m.in. w pisarstwie Gila Anidjara. Proponowane przez niego analizy dowodzą, że powiązania między antysemityzmem i islamofobią są głęboko zakorzenione w europejskiej historii i ściśle wiążą się z tym, jak chrześcijańska/sekularyzująca się Europa definiowała swoich żydowskich i muzułmańskich innych, jednocześnie wytwarzając i zacierając różnice między nimi, a także tworząc i niwelując dystans między sobą a każdym z nich (jak również między nimi samymi). Według Anidjara ta historyczna gra nieustannych resygnifikacji jest w istocie procesem par excellence teologiczno-politycznym, w toku którego wykuwają się europejskie pojęcia religii i polityki. Sam koncept wroga, funkcjonujący w europejskim imaginarium filozoficznym, jest w jego opinii ustrukturyzowany przez powiązane ze sobą i ostatecznie spolaryzowane figury Żyda i Araba, a dokładniej „poprzez stosunek Europy zarówno do Araba jaki Żyda”. Stwierdzając, że to, co religijne i to, co polityczne, pojawia się jako różnica religia konstytuowana jest jako różnica między religiami, a to, co polityczne, wyłania się z podziałów religijnych - autor dochodzi do wniosku, że „Żyd, Arab stanowią warunek religii i polityki"3.

W kontekście spostrzeżeń Gila Anidjara dyskursy antysemickie i antyislamskie, we wszystkich swoich historycznie zmiennych, wielorakich formach, jawią się więc nie tyle jako wyraz nieskoordynowanych i irracjonalnych paroksyzmów wrogości i strachu przed „Innym” czy też - zaledwie - jako „powierzchnia retoryki, w którą oblekają się powszechne postawy wobec innego" ". Okazują się one raczej rezerwuarem przekształcających się w czasie i wzajemnie ze sobą powiązanych sposobów konstytuowania europejskich (chrześcijańskich/zsekularyzowanych) wspólnot politycznych i tożsamości. Rola antysemityzmu w budowaniu tych wspólnot jest w literaturze przedmiotu dobrze rozpoznana, podobnie zresztą jak rola orientalistycznych odniesień do tego, co islamskie. Uderzające i symptomatyczne zarazem

2 G. Anidjar The Jew, the Arab. A History of the Enemy, Stanford University Press, Palo Alto 2003, s. vi.

3 Tamże, s. vi.

4 S.L. Gilman Self-Hatred. Anti-Semitism and the Hidden Language of Jews, Johns Hopkins University Press, Baltimore-London 1990, s. X. (cyt. za: J. Tokarska-Bakir Legendy o krwi. Antropologia przesq̨du, W.A.B., Warszawa 2008). 
jest jednak to, że te dwa nurty badań rozwijają się w niemal całkowitym oddzieleniu.

Poniższy tekst jest próbą pokonania tego oddzielenia. Jego punktem wyjścia jest przekonanie, że procesu konstytuowania się jakiejkolwiek tożsamości lub wspólnotowości nie da się satysfakcjonująco opisać bez wyjścia poza standardową analizę, która koncentruje się na tym, jak tożsamość ustanawia się przez odniesienie do tego, co wobec niej inne. Uważniejsza refleksja nad historycznymi trajektoriami antysemityzmu i islamofobii pokazuje bowiem, że w przypadku europejskich (chrześcijańskich/zsekularyzowanych) wspólnot i tożsamości kluczowym elementem odnoszenia się do wspomnianej „inności” jest konceptualne i polityczne żonglowanie różnymi kategoriami „innych", a więc m.in. kategoriami „żyda” i „muzułmanina”, „Żyda” i „Araba”. Szczególnie istotny jest tutaj fakt, że kategorie te w żaden sposób nie dają się wpisać w binarny podział na (europejską/ chrześcijańską/zsekularyzowaną) tożsamość i (pozaeuropejską/niechrześcijańską/religijną) nie-tożsamość. Współtworzą one raczej skomplikowaną geometrię inności/tożsamości, w której inność jest zawsze stopniowalna, warunkowa i wieloraka i w której kształt tożsamości zależy zarówno od jej relacji wobec tego, co inne, jak i od konkretnych konfiguracji różnych form inności.

Wyjątkowe znaczenie figur „żyda” $i$ „muzułmanina” w tych powikłanych geometriach inności/tożsamości wiąże się z faktem, że w hegemonicznych wyobrażeniach tego, co europejskie, chrześcijaństwo odgrywa niepodzielnie rolę „definicyjną". Żydzi i muzułmanie, jako przedstawiciele wielkich „religii Abrahamowych", odgrywają w nich zatem rolę innych szczególnie istotnych, bo szczególnie bliskich. Znaczeń zawartych w figurze „żyda” $\mathrm{i}$ „muzułmanina" nie można jednak sprowadzić do kwestii teologicznych. Dzieje się tak dlatego, że historycznie, w swojej religijnej postaci, figury te stanowiły tylko jeden ze sposobów kodowania odmienności, która w innym miejscu i czasie była (i jest) wyrażana za pomocą ewoluujących i przenikających się kategorii rasy, etniczności czy narodu. Zestawiając ze sobą figury żyda i muzułmanina, Żyda i Araba, trzeba także zauważyć, że w różnym czasie i miejscu nabierały one ostrości lub ją traciły - z racji bliskości lub dystansu, który w konkretnych okolicznościach dzielił chrześcijańską/zsekularyzowaną większość w Europie od wyznawców judaizmu i islamu (lub ich zeświecczonych odpowiedników).

Podążając za Gilem Anidjarem w poniższym tekście podejmuję próbę uchwycenia integralnych, choć czasami antytetycznych i skrywanych więzi, które w europejskim (chrześcijańskim/zsekularyzowanym) imaginarium 
łączyły żydów i muzułmanów, Żydów i Arabów. Moim głównym celem jest wstępne zarysowanie owej wspominanej powyżej, nie-binarnej geometrii inności/tożsamości, a dokładniej - zasygnalizowanie sposobów, na jakie ewoluowała ona w europejskiej historii. Jak pokażę, najogólniejszy kierunek tej ewolucji przebiega od etapu, na którym różnorodne wyobrażenia na temat żydów i muzułmanów, Żydów i Arabów zawierały często przekonanie o ich rozmaicie rozumianym pokrewieństwie i bliskości, do etapu, w którym następuje radykalne symboliczne i polityczne zerwanie między tym, co żydowskie i tym, co muzułmańskie/arabskie. W moim przekonaniu znajomość tej ewolucji powinna być punktem wyjścia do wszelkiej refleksji nad współczesnym antysemityzmem i islamofobią.

\section{Historia zapomnianych więzi}

Bliskość tego, co żydowskie i tego, co arabskie/muzułmańskie została najdobitniej wyrażona zapewne przez zdelegitymizowaną dziś kategorię „Semitów", wprowadzoną przez XVIII i XIX-wieczne językoznawstwo. Ta nowa wówczas dziedzina nauki, odkrywając poszczególne grupy językowe (indoeuropejską, semicką, orientalną), jednocześnie przypisała społeczeństwom posługującym się określonymi językami konkretne cechy związane z rzekomymi własnościami ich mowy. Z racji pokrewieństwa języka arabskiego i hebrajskiego Żydzi i Arabowie (ci drudzy jako "paradygmatyczni" rzekomo muzułmanie) zostali oficjalnie zaklasyfikowani jako należący do jednej kategorii. Jak mówi Gil Anidjar, to „wynalezienie Semitów” oznaczało „historycznie wyjątkowy, dyskursywny moment, zgodnie z którym cokolwiek mówi się o Żydach może być również powiedziane o Arabach, i vice versa"5. Takie postrzeganie Żydów i Arabów widać np. w pracach Ernesta Renana, u którego silne przeciwstawienie chrześcijaństwa z jednej strony oraz judaizmu i islamu z drugiej wiąże się z tendencją do akcentowania różnicy między „Wschodem” i „Zachodem” w kategoriach rasowych. Pisząc o funkcjonowaniu językoznawczych klasyfikacji, Tomoko Masuzawa zauważa, że „znaczna większość XIX-wiecznych filologów utrzymywała, iż w porównaniu z tą pierwszą rodziną [języki indoeuropejskie], druga grupa języków [semicka] była zdecydowanie niedoskonała i nie w pełni rozwinięta, jeśli chodzi o możliwości fleksji. Z tą niedoskonałością wiązały się wszelkie ograniczenia, które charakteryzowały grupy posługujące się danym językiem

5 G. Anidjar Semites. Race, Religion, Literature, Stanford University Press, Palo Alto 2008, s. 18. 
jako rasę"”. „Semickość” okazywała się zatem kategorią łączącą kwestie lingwistyczne, „rasowe” i religijne, przy czym na ogół służyła jako synonim nieeuropejskiej niższości, choć - jak pokazują Kalmar i Penslar - na fali romantyzujących nurtów orientalizmu bywała także znakiem egzotycznego „szlachectwa” i nobilitującej przynależności do „antycznej rasy”.

Narodziny i rozpad kategorii Semitów są kluczowym momentem historycznym dla wszelkich prób zrozumienia powiązań między antysemityzmem i islamofobią. Jednak historia utożsamiania żydów i muzułmanów jest znacznie dłuższa i w powiązaniu z epizodem "semickim” zasadniczo komplikuje utrwalony obraz relacji między trzema religiami „Abrahamowymi”. Dotyczy to zwłaszcza szczególnej współczesnej konfiguracji tych relacji, która przez pojęcie „tradycji judeochrześcijańskiej” akcentuje bliskość judaizmu i chrześcijaństwa, dystansując je jednocześnie od islamu. Historia żydowsko-muzułmańskich więzi sięga w istocie głębokiego średniowiecza oraz samych początków islamu. Bernard Lewis określa te więzi mianem kultury „judeo-islamskiej", stwierdzając przy tym, że o jej istnieniu można mówić do wieku $\mathrm{XX}^{8}$. W podobnym duchu pisze Léon Poliakov, który analizuje stosunki między żydami i muzułmanami w średniowiecznych imperiach muzułmańskich, pokazując przy tym integralne związki między islamem i judaizmem. Związki te nie wyczerpywały się w tradycyjnym konsensusie dotyczącym wspólnego pochodzenia Żydów i Arabów od Abrahama, którego pierworodny syn, Izmael, miał być przodkiem ludów arabskich. Polegały natomiast z jednej strony na silnym wpływie tradycji żydowskiej na rozwój religijnej doktryny islamu', z drugiej - na znaczeniu, jakie muzułmańska kultura intelektualna miała dla rozwoju żydowskiej teologii (rozwijanej zresztą często w języku arabskim oraz w instytucjach wspieranych przez muzułmańskich władców $\left.{ }^{10}\right)$.

Intelektualna wymiana między judaizmem $\mathrm{i}$ islamem nie byłaby możliwa, gdyby nie polityka religijnej koegzystencji, która obowiązywała na terenach muzułmańskich. Analizując mniejszościowy status wspólnot żydowskich

6 T. Masuzawa, The Invention of World Religions. Or, How European Universalism Was Preserved in the Language of Pluralism, The University of Chicago Press, Chicago 2005, s. 25.

7 I. Davidson Kalmar, D.J. Penslar (eds.) An Introduction, w: I. Davidson Kalmar, D.J. Penslar (eds.) Orientalism and the Jews, Brandeis University Press, Lebanon 2005, s. XXVII-XXVIII.

8 B. Lewis The Jews of Islam, Princeton University Press, Princeton 1984, s. X. Zob. np. J. Gnilka Koran i chrześcijanie. Tajemnice początków, Jedność Herder, Kielce 2010.

10 L. Poliakov Historia antysemityzmu. Epoka wiary, Universitas, Kraków 2008, s. 61. Zob. także B. Lewis The Jews of Islam, s. 73, 80. 
na tych terenach, Poliakov podkreśla, że mimo okazjonalnych konfliktów z muzułmanami czy mniejszościami chrześcijańskimi, czasami rzeczywiście przybierającymi krwawe formy, sytuacja tych wspólnot pozwalała im na wszechstronny rozwój kulturalny i ekonomiczny ${ }^{11}$. Okoliczności te sprawiały, że - jak pisze autor - „Żydzi wschodni mieli w pogardzie i uznawali za gorszych swoich nieszczęsnych braci europejskich"12 żyjących pod rządami chrześcijan $^{13}$. Z perspektywy refleksji na temat podziałów religijnych i rozpowszechnionego dziś przekonania o „istotowej” obcości między judaizmem i islamem interesujące jest to, że dobre na ogół stosunki między żydami i muzułmanami, których łączyło pokrewieństwo kulturowe i językowe, przekładały się często na wspólne praktyki religijne. Jak stwierdza Poliakov, „czysto religijne nauczanie islamu ułatwiało współistnienie żydów i muzułmanów do tego stopnia, że należy wnosić, iż wobec braku sprzeczności między tymi dwoma wyznaniami, można było przynależeć do nich równocześnie"14.

Wzorcowym, być może nieco wyidealizowanym, przykładem pokojowej i twórczej koegzystencji muzułmańsko-żydowskiej, a właściwie muzułmańsko-żydowsko-chrześcijańskiej, pozostaje średniowieczna Hiszpania. Dotyczy to szczególnie Andaluzji, zwanej po arabsku al Andalus, która stała się symbolem wieloetnicznej i wieloreligijnej kultury cechującej się otwartością i tolerancją, a także szczególną atencją dla życia intelektualnego, naukowego i artystycznego ${ }^{15}$. W okresie swojego największego rozkwitu muzułmańskie miasta Półwyspu Iberyjskiego były miejscem, w którym przenikające się kultury żydowska i chrześcijańska przyjmowały zarabizowane formy ${ }^{\mathbf{1 6}}$. Dla

11 Jak pisze Bernard Lewis, nie dotyczyło to tylko mniejszości żydowskich: „Pod wieloma względami pozycja nie-muzułmanów pod tradycyjną władzą islamską była o wiele łatwiejsza niż pozycja nie-chrześcijan czy nawet chrześcijańskich heretyków w średniowiecznej Europie", B. Lewis The lews of Islam, s. 62.

L. Poliakov Historia antysemityzmu. Epoka wiary, s. 68.

13 Bernard Lewis stwierdza w tym kontekście, że „przez większość średniowiecza Żydzi islamu stanowili większą i bardziej aktywną część żydowskiego ludu... z niewieloma wyjątkami wszystko, co twórcze i znaczące w żydowskim życiu zdarzyło się na terenach muzułmańskich", B. Lewis The lews of Islam, s. 68. L. Poliakov Historia antysemityzmu. Epoka wiary, s. 63.

Zob. M.R. Menocal Ozdoba świata. Jakmuzułmanie, żydzi i chrześcijanie tworzyli kulturę tolerancji wśredniowiecznej Hiszpanii, Wydawnictwo UJ, Kraków 2006.

Bazę dla międzyreligijnych i międzyetnicznych więzi stanowił język arabski, zarówno żydzi, jak i chrześcijanie posługiwali się nim, używając własnych alfabetów. W konsekwencji, jak zauważa, Lewis, różnice między muzułmanami, chrześcijanami i żydami stawały się relatywnie nie- 
historii powiązań między judaizmem i islamem (a także dla historii sposobów, na jakie - z chrześcijańskiej perspektywy - postrzegano żydowską i muzułmańską odmienność) znaczący jest jednak nie tylko etap twórczego współistnienia tych religii w średniowiecznej Hiszpanii. Istotne jest także podobieństwo losów, jakie stały się udziałem żydów i muzułmanów w wyniku chrześcijańskiej rekonkwisty tego kraju i przemian politycznych wczesnej nowożytności. W obu przypadkach losy te zostały naznaczone chrześcijańskimi prześladowaniami, przymusowymi konwersjami i wreszcie wygnaniem. Jak zauważa Ivan Davidson Kalmar, ślady rozmaicie rozumianego pokrewieństwa żydów i muzułmanów są silnie obecne w chrześcijańskim imaginarium średniowiecza. Pokrewieństwo to wiąże się z faktem, że dla europejskich chrześcijan wzorem do zrozumienia odmienności muzułmanów byli właśnie żydzi, z drugiej strony - sami żydzi byli symbolicznie kojarzeni z „orientalną” Ziemią Świętą. Analizując wybrane dzieła malarskie, które powstawały od średniowiecza do XIX wieku, Kalmar stwierdza, że „w sztuce chrześcijańskiej powszechną praktyką jest przedstawianie biblijnych Żydów jak gdyby byli muzułmanami"17. Według tego autora zabieg wizualnego orientalizowania ${ }^{18}$ żydów miał zawsze na celu przeciwstawienie ich „okcydentalnemu" Jezusowi i tym samym zaakcentowanie różnicy między żydowską tradycją Starego Testamentu a chrześcijaństwem. (Jak zauważa Sander

istotne: „dużo ważniejsza była wspólnota języka i wyrażonych w nim wartości - cała kulturowa rama odniesienia, która w znacznym stopniu umożliwiła komunikację i współpracę, mającą niewiele odpowiedników w historii diaspory żydowskiej", B. Lewis The Jews of Islam, s. 78.

17 I. Davidson Kalmar Jesus Did Not Wear a Turban: Orientalism, the Jews, and Christian Art, w: I. Davidson Kalmar, D.J. Penslar (eds.) Orientalism and the Jews, s. 3.

18 Na marginesie warto zauważyć, że równoległa orientalizacja żydów i muzułmanów w wyobrażeniach średniowiecznych nie wiązała się początkowo z konstruowaniem tych ostatnich w kategoriach zewnętrzności wobec "chrześcijańskiej Europy". Orient jako miejsce biblijnych wydarzeń miał raczej charakter mitologiczny i teologiczny i nie oznaczał etnograficznej czy geograficznej obcości. Stał się synonimem tej obcości dopiero u progu nowożytności. W średniowieczu orientu nie utożsamiano $\mathrm{z}$ islamem, podobnie zresztą jak nie traktowano islamu jako należącego do innego, niezachodniego świata. Takie tożsamościowo-geograficzne klasyfikacje nie były jeszcze możliwe, częściowo także dlatego, że z jednej strony chrześcijanie byli ciągle obecni w Anatolii, z drugiej - muzułmanie na Półwyspie Iberyjskim. Identyfikacja orientu z islamem rozpoczyna się wraz z końcem XIV wieku, kiedy też - dzięki rozwojowi Imperium Otomańskiego - typowym muzułmańskim wrogiem stają się "Turcy", a nie "Saraceni" (ci stopniowo znikają z chrześcijańskich wyobrażeń wraz z ich wygnaniem z Sycylii i Hiszpanii). Kluczową datą w tym procesie jest rok 1453, w którym wojska Imperium Otomańskiego zdobywają Konstantynopol i czynią go swoją stolicą, co nie tylko oznacza koniec chrześcijańskiego Cesarstwa Bizantyjskiego, ale także zdławienie nadziei na chrześcijański podbój Jerozolimy. 
L. Gilman, zabieg orientalizowania Żydów był ciągle stosowany w XVIII-wiecznych europejskich karykaturach, zwłaszcza brytyjskich, w których „standardowym wizerunkiem Żydów... był maltański Żyd w orientalnym turbanie"19). Nieco inną interpretację obecności postaci o „muzułmańskim" wyglądzie w artystycznych reprezentacjach scen z udziałem Jezusa proponuje Gil Anidjar. Sugeruje on, że w reprezentacjach tych chodziło o przedstawienie Jezusa jako „ofiary ciemnoskórych Saracenów”, co z kolei oznaczało anachroniczne włączenie muzułmanów do grona „zabójców Chrystusa" (i tym samym skojarzenie ich z żydami) ${ }^{20}$. W tym kontekście Anidjar podkreśla także, że w pismach pisarzy chrześcijańskich od VII wieku muzułmanie nierzadko byli określani jako „nowi żydzi”, a ich praktyki jako „żydowskie” albo pod żydowskim wpływem. Według Suzanne Conklin Akbari same narodziny islamu były często postrzegane jako „perwersyjny zwrot ku” "prawu Mojżesza"21. Łączenie żydów z muzułmanami powszechne było również $\mathrm{np}$. w kontekście opowieści o zdobyciu przez muzułmanów Hiszpanii - w Pieśni o Rolandzie w odwecie za śmierć głównego bohatera niszczone są zarówno synagogi, jak i meczety.

Chrześcijańskie postrzeganie muzułmanów łączyło się często z próbami demonizowania ich i samego islamu według wzorów stosowanych wobec żydów. Mahomet był niekiedy przedstawiany jako wybraniec szatana ${ }^{22}$, którego pomoc pozwalała wyjaśnić niezrozumiałe dla chrześcijan z teologicznego punktu widzenia sukcesy muzułmanów ${ }^{23}$. Schematy wrogości czasem odwracały się: w epoce wypraw krzyżowych to antymuzułmańska wrogość odbiła się rykoszetem na społecznościach żydowskich (często mimo oficjalnej polityki władz zdeterminowanych do ich ochrony, choć już nie do walki

19 Ale, jak mówi Gilman, już „W XIX wieku był to Lord Rothschild w oficjalnym stroju przyjmujący księcia Walii na ślubie swojej córki w londyńskiej synagodze", S.L. Gilman Multiculturalism and the Jews, Routlege, New York 2006, s. 8.

20 G. Anidjar The Jew, the Arab..., s. 34.

21 S. Conklin Akbari Placing the Jews in Late Medieval Literature, w: I. Davidson Kalmar, D.J. Penslar (eds.) Orientalism and the Jews, s. 35. Zob. również S. Heschel Judaism, Christianity and Islam. Prelude of Revisionist Configuration, w: tejże Abraham Geiger and the /ewish Jesus, University of Chicago Press, Chicago 1998, s. 60-61.

R. Firestone Islamophobia and Anti-Semitism: History and Possibility, w: Islamophobia and Anti-Muslim Hatred: Causes \& Remedies, "Arches Quarterly" Winter 2010 Vol. 4, edition 7, s. 47. boje islamskiego wroga?", I. Davidson Kalmar, D.J. Penslar (eds.) An Introduction, w: I. Davidson Kalmar, D.J. Penslar (eds.) Orientalism and the Jews, s. XXVI. 
z grupową dyskryminacją ${ }^{24}$ ). Żydzi stali się zatem ofiarą dyskursu, który rozciągnął tę wrogość „na wszystkich wrogów Pana i jego wybranych chrześcijańskich wyznawców” i który domagał się „zemsty na tych wszystkich, którzy rzekomo wyrządzali szkodę chrześcijanom i chrześcijaństwu"25. Fakt ten prowadzi zresztą niektórych badaczy do stwierdzenia, że średniowieczny antysemityzm był w istocie funkcją nastawień antyislamskich tego okresu. Stwierdzenie to wiąże się z obserwacją, że antysemityzm w Europie intensyfikuje się dokładnie w momencie, kiedy islam staje się realnym zagrożeniem dla świata chrześcijańskiego, a więc w XI-XIV wieku ${ }^{26}$. Jak pisze Reuven Firestone, wzmożenie antysemityzmu w okresie wojen krzyżowych zaowocowało tym, że na niektórych obszarach żydzi zaczęli pokładać szczególne nadzieje w muzułmanach, których postrzegali jako podobnych sobie i których szanowali za kulturową wyższość nad chrześcijanami ${ }^{27}$.

\section{Kodowanie wrogości: między teologią a polityką}

Zgodnie z wspominaną wcześniej obserwacją Gila Anidjara, w chrześcijańskim imaginarium mamy do czynienia zarówno z fenomenem utożsamienia żydów i muzułmanów, jak i z wytwarzaniem między nimi różnicy. Żydzi i muzułmanie z jednej strony byli bowiem postrzegani przez pryzmat wspólnych im cech charakterystycznych (rzeczywistych lub wyobrażonych), z drugiej - byli dla chrześcijan wrogami innego rodzaju: pierwsi przede wszystkim teologicznymi, drudzy - politycznymi i militarnymi.

Wbrew rozpowszechnionym wyobrażeniom, bazującym na esencjalistycznym rozumieniu podziałów religijnych, kontakty między społecznościami chrześcijańskimi i przedstawicielami „świata islamu” nie były w średniowieczu postrzegane zawsze w kategoriach antagonizmu religijnego. Czynnik

24 Warto w tym kontekście przywołać rozstrzygnięcia legislacyjne, zgodnie z którymi po Soborze Laterańskim III (1179) prawo kanoniczne traktowało żydów i muzułmanów jako należących do jednej kategorii (kilkadziesiąt lat później Sobór Laterański IV wystosował nakaz, aby obie te grupy nosiły na ubraniach oznaczenia umożliwiające odróżnienie ich od chrześcijan).

R. Chazan Medieval Stereotypes and Modern Antisemitism, University of California Press, Berkeley 1997, s. 5 . Zob. A. Harris Cutler, H. Elmquist Cutler The Jew As Ally of the Muslim: Medieval Roots of Anti-Semitism, University of Notre Dame Press, Notre Dame, Ind. 1986. zwoliciela od chrześcijańskiego ucisku, R. Firestone Islamophobia and Anti-Semitism: History and Possibility, s. 47 . 
religijny był bowiem w tych kontaktach często zdominowany przez wymogi bieżącej polityki. Pisze o tym Franco Cardini, który odmalowując skomplikowany pejzaż krzyżujących się militarnych i politycznych sojuszy i konfliktów między władcami chrześcijańskimi i muzułmańskimi na Półwyspie Iberyjskim we wczesnym średniowieczu, stwierdza: „wbrew temu, co wynikało z późniejszych interpretacji politycznych bądź dzieł epickich, które pokryły owe wydarzenia grubą warstwą patyny religijnej, żadna z układających się stron nigdy nie żywiła uprzedzeń wynikających z odmiennej wiary bądź z faktu, że muzułmańscy wrogowie emira Kordoby będą walczyć u boku chrześcijan przeciwko współwyznawcom"28. Także w kontekście późniejszych wypraw krzyżowych trudno mówić o oczywistości binarnej wizji konfliktu między „islamem” a „chrześcijaństwem”. Powodem tego są, po pierwsze, konflikty rozdzierające sam świat chrześcijański i zaznaczające się w podziałach między Cesarstwem Bizantyjskim a łacińskim Zachodem, po drugie fakt, że samo Bizancjum, zwracając się do papieża z prośbą o militarną pomoc w tłumieniu arabskich i tureckich najazdów bynajmniej nie postrzegało ich w kategoriach zagrożenia religijnego. Znaczące jest także to, że sami bliskowschodni muzułmanie nie postrzegali wojen krzyżowych jako motywowanych religijnie, ich interpretacja jako „zderzenia” dwóch wielkich „cywilizacji religijnych” przyszła znacznie później29.

W przypadku chrześcijańskiej wrogości wobec żydów kwestie teologiczne miały znaczenie kluczowe. Aby ugruntować swoją tożsamość jako odrębnego projektu religijnego chrześcijaństwo, inkorporując część tradycji judaistycznej, musiało jednocześnie odmówić wierze żydów teologicznej prawomocności ${ }^{30}$. Jak mówi Susannah Heschel, „chrześcijaństwo skolonizowało judaizm, przejmując jego centralne teologiczne koncepcje mesjasza, eschatologii,

F. Cardini Europa a islam: historia nieporozumienia, Wydawnictwo UJ, Kraków 2006, s. 21.

29 Jak pisze Cécile Morrison, muzułmanie nie brali pod uwagę „aspektu religijnego krucjat, a w nich samych widzieli wojska podobne do armii, z którymi w końcu X wieku wkraczali do Syrii cesarze bizantyjscy Nicefor Fokas i Jan Tzimiskes. Franków uznano bez zbędnych dywagacji za nowego partnera w złożonej grze politycznej peryferii Wschodu muzułmańskiego", C. Morrisson Krucjaty, AGADE, Warszawa 1997, s. 29.

Ten chrześcijański gest historyczno-teologicznej delegitymizacji judaizmu dobrze oddają słowa Ernesta Renana: „Chrześcijaństwo jest odgałęzieniem czy raczej... punktem dojścia lub przyczyną celową judaizmu. Zrodziwszy chrześcijaństwo judaizm ciągle trwa, ale jako uschnięty pień obok płodnej gałęzi, pozbawiony życia. Jego historia, choć nadal głęboko interesująca, ma tylko drugorzędne znaczenie w szerszej historycznej perspektywie, E. Renan History of the People of Israel, cyt. za T. Masuzawa The Invention of World Religions, s. 177. 
apokaliptyzmu, bycia narodem wybranym oraz Izraela, przejęło również jego Pismo, proroków, a nawet Boga, pozbawiając te idee znaczenia, jakie miały one dla judaizmu. W konsekwencji między chrześcijaństwem i judaizmem istnieje wyjątkowa relacja... judaizm zaczyna w chrześcijańskiej teologii funkcjonować jako Inny, którego zanegowanie potwierdza, a nawet konstytuuje chrześcijaństwo" ${ }^{\text {31 }}$. Ta „wyjątkowa relacja”, polegająca na jednoczesnej teologicznej zależności i negacji, w znaczący sposób ukształtowała chrześcijańską percepcję żydowskiej obcości. Szczególnie istotnym jej komponentem była rola w ukrzyżowaniu Jezusa, którą przypisano żydom jako grupie, oraz nadane im miano „bogobójców”. Warto zauważyć, że niczego porównywalnego nie można znaleźć w relacjach między judaizmem i islamem. Okazjonalna niechęć między wyznawcami tych religii nigdy nie miała teologicznego ugruntowania - jeśli się pojawiała, była raczej wyrazem napięć o charakterze politycznym lub ekonomicznym ${ }^{32}$. Faktem jest, że już w średniowieczu chrześcijańska wrogość wobec żydów przyjmowała także nieteologiczne formy, z oczywistych powodów nie wiązały się one jednak nigdy z interakcjami o charakterze polityczno-militarnymi - jak w przypadku relacji chrześcijańsko-muzułmańskich. Były natomiast związane z animozjami grupowymi odnoszącymi się do ekonomiczno-społecznych aspektów funkcjonowania mniejszości żydowskich w społecznościach europejskich. Jak zauważa Robert Chazan, w późnym średniowieczu tworzą się antyżydowskie wyobrażenia bazujące nie tyle na religijnie definiowanej „winie” żydów, co raczej na ich domniemanym oszukańczym i niegodziwym usposobieniu ${ }^{33}$. Wyobrażenia te będą towarzyszyć żydom przez następne stulecia także tam, gdzie religijny komponent ich tożsamości zostanie zapomniany lub zmarginalizowany.

Teologiczna relacja między chrześcijaństwem i islamem przedstawiała się odmiennie niż relacja między chrześcijaństwem i judaizmem. W kontekście średniowiecznych wyobrażeń trudno zresztą mówić o koncepcji islamu jako osobnej „religii”, która w wyczerpujący i ostateczny sposób miałaby

31 S. Heschel Theology as a Vision for Colonialism From Supersessionism to Dejudaization in German Protestantism, w: Germany's Colonial Pasts, ed. by E. Ames, M. Klotz, L. Wildenthal, University of Nebraska Press, Lincoln 2009, s. 148-149.

„Żydzi nie przedstawiali sobą zagrożenia dla islamskiego porządku świata, nie byli też wyzwaniem dla muzułmańskiej wiary, ani też - w przeciwieństwie do chrześcijan - nie konkurowali z muzułmanami o przyciągnięcie wciąż nienawróconych pogan", B. Lewis The Jews of Islam, s. 86 . 
definiować tożsamości i wartości swoich wyznawców. Częściowo wynikało to $\mathrm{z}$ niewielkiej wiedzy, jaka na temat muzułmanów była dostępna w Europie. Częściowo natomiast ze specyficznego średniowiecznego rozumienia religii, któremu obce było myślenie w kategoriach pluralizmu odrębnych, pełnoprawnych systemów teologicznych ${ }^{34}$. Jak pisałam wcześniej, islam bywał postrzegany jako wariant judaizmu, z drugiej jednak strony traktowano go czasem jako formę chrześcijańskiej herezji. Ivan Kalmar i Derek J. Penslar stwierdzają np., że „o „uzurpatorze” Mahomecie nie myślano [w średniowieczu] jako o outsiderze bez związków z chrześcijaństwem, ale raczej jako rodzaju schizmatyka, który rzucił wyzwanie kościelnej tradycji, tym samym się z nią wiążąc"35. Na poparcie swojej obserwacji autorzy przywołują fragmenty z Boskiej komedii Dantego i - w opozycji do interpretacji Edwarda Saida stwierdzają, że Mahomet nie jest tam przedstawiony jako postać zewnętrzna wobec europejskiej cywilizacji, ale właśnie jako schizmatyk ${ }^{36}$, który wraz ze swoim zięciem Alim trafia do części piekła przeznaczonej dla setki innych chrześcijańskich grzeszników ${ }^{37}$.

Chrześcijańskie wyobrażenia na temat islamu okazują się zatem zmienne i niestabilne. W niektórych okresach historycznych islam jawi się chrześcijanom jako herezja lub wariant judaizmu, a więc jako fenomen pozbawiony odrębnej tożsamości teologicznej. W innych zaczyna funkcjonować jako religia, do której istoty należy fanatyzm i skłonność do ekstremizmu. W jeszcze innych muzułmanów postrzega się głównie przez pryzmat relacji militarno-politycznych, a czynnik teologiczny niemal całkowicie znika z pola widzenia.

Myślenie takie rozwija się dopiero w nowożytności, kiedy to chrześcijaństwo samo siebie zaczyna nazywać "religią", a nie "chrześcijaństwem", co oznacza, że samo siebie zaczyna rozumieć jako religię pośród innych religii (a nie jako „Kościół w konfrontacji z żydami, muzułmanami i innymi heretykami"), G. Anidjar Semites. Race, Religion, Literature, s.6o.

I. Davidson Kalmar, D.J. Penslar (eds.) An Introduction, w: Orientalism and the /ews, s. XXV.

Pisze o tym także Léon Poliakov, który przywołuje również inne legendy przedstawiające muzułmanów jako chrześcijańską heretycką sektę. Zob. L. Poliakov, Historia antysemityzmu. Epoka wiary, s. 45 .

Obaj wspomniani są w części zatytułowanej Piekło, w pieśni XXVIII, w której narrator spotyka szczególną kategorię grzeszników nazwaną przez Dantego "siewcy niezgody”. Wina Mahometa i Alego nie jest zatem określona w kategoriach religijnych, ale polega na wywoływaniu konfliktów i dzieleniu ludzi. „Patrz, jak kaleki Mahomet! - zawołał - / a tam przede mną płacząc idzie Ali z twarzą rozprutą od brody do czoła, / i wszyscy inni, co się tu zebrali, / tak pokrajani chodzić muszą za to, / że tam niezgodę w świecie rozsiewali". D. Alighieri Boska komedia, Wydawnictwo Antyk, Kęty 2001, s. 160 (wersy 31-36). 
Paradoksalnie jednak właśnie w średniowieczu, traktowanym często jako „epoka wiary”, znajdujemy różne niereligijne sposoby postrzegania reprezentantów „świata islamu”. Szczególnie interesującym, literacko-filozoficznym przykładem odreligijnionego postrzegania Arabów/muzułmanów jest XII-wieczna rozprawa Piotra Abelarda zatytułowana Rozmowa pomiędzy filozofem, Żydem i chrześcijaninem. Wiele wskazuje na to, że jeden z jego tytułowych bohaterów, filozof, określony w tekście jako „poganin”, jest w istocie Arabem, a jednocześnie - odteologizowaną figurą muzułmanina ${ }^{38}$.W tekście uderzające jest to, że podstawową cechą, która odróżnia go od Żyda i chrześcijanina, jest przede wszystkim jego odmienna formacja intelektualna oraz filozoficzne, a nie religijne źródła przyjmowanej przez niego etyki. Abelard podkreśla, że filozof „zadowala się prawem natury"39, co oznacza, że jego myślenie nie tyle bazuje na religijnych dogmatach, co na rozumie. $Z$ tego powodu dialog z nim w ogóle jest możliwy tylko na bazie rozumu a nie wiary ${ }^{40}$.

Jak się wydaje, to odreligijnione postrzeganie arabskiej/muzułmańskiej odmienności odzwierciedla szczególny stosunek chrześcijańskich elit do kultury arabskiej, który rozwinął się od końca XI wieku. Był to czas, w którym elity te po raz pierwszy miały okazję bliżej zetknąć się z intelektualną, artystyczną i materialną kulturą Arabów (i muzułmanów w ogóle) i odkryć jej bogactwo, nieporównywalne do europejskich osiągnięć tego okresu. Sam Abelard przyznawał, że zdolność posługiwania się rozumem, przeciwstawioną posłuszeństwu autorytetu, zawdzięcza Arabom ${ }^{41}$. Po tym jak władze kościelne ograniczyły mu możliwość wykładania, mnich miał powiedzieć, że

38 Arabska czy muzułmańska tożsamość filozofa nie jest w tekście wyrażona explicite, jednak już w pierwszych zdaniach Abelard przedstawia filozofa jako wyznawcę monoteistycznego Boga, należącego do innej religii niż żyd i chrześcijanin. Decydująca wydaje się jednak wypowiedź żyda, w której zwracając się do filozofa, wspomina on o jego ludzie jako pochodzącym od biblijnego Izmaela, uważanego tradycyjnie za praojca Arabów, P. Abelard Rozmowa pomiędzy filozofem, Żydem i chrześcijaninem, w: tegoż Rozprawy, Pax, Warszawa 1969, s. 35.

Tamże, s. 7.

Przekonanie to poprzedza podobne stwierdzenie u św. Tomasza, według którego przeciw żydom można argumentować na bazie Starego Testamentu, przeciw heretykom - na bazie Nowego, ponieważ jednak "mahometanie" nie przyjmują tych argumentów, komunikacja z nimi możliwa jest tylko dzięki odwołaniom do „rozumu naturalnego. Zob. Tomasz z Akwinu Summa contra gentiles: prawda wiary chrześcijańskiej w dyskusji z poganami, innowiercami i błądzq̨cymi, Wydawnictwo W drodze, Poznań 2003. 
z rozpaczy myśli o „opuszczeniu obszaru chrześcijaństwa i udaniu się do «pogan» (Saracenów)"42. Przykład Abelarda pokazuje, że specyficzny charakter kontaktu ze „światem islamu” w średniowieczu sprawił, iz - przynajmniej w dyskursach elit intelektualnych - muzułmańska odmienność nie była artykułowana w kategoriach nieprzekraczalnej różnicy religijnej czy teologicznego antagonizmu, ale wyrażała się w uznaniu muzułmańskiej wyższości kulturowej czy intelektualnej.

Biorąc pod uwagę historyczną różnorodność chrześcijańskiego postrzegania islamu, Gil Anidjar zwraca uwagę na dziejową transformację, dzięki której islam zaczął być jednoznacznie postrzegany jako „religia”43 a następnie stał się symboliczną antytezą „cywilizacji świeckiej” i przeciwieństwem zsekularyzowanej Europy ${ }^{\mathbf{4 4}}$. Kontekstem tego procesu okazuje się radykalna zmiana w europejskim rozumieniu „orientu”, której źródłem było powolne wydobywanie się Europy ze stanu ekonomicznej, politycznej, kulturowej i technologicznej niższości wobec krajów Wschodu, zwłaszcza Chin i Indii, ale także Imperium Osmańskiego, a wcześniej - imperiów arabskich. Dopiero ta zmiana, przez niektórych badaczy datowana koniec XVIII wieku ${ }^{45}$, tworzy podwaliny dla idei europejskiej hegemonii i bazujących na niej kategoryzacjach dotyczących nieeuropejskich, niechrześcijańskich innych. Jednym $\mathrm{z}$ instrumentów tych kategoryzacji, szczególnie istotnym w konstruowaniu europejskiego obrazu społeczeństw muzułmańskich, będzie nowoczesne pojęcie „religii”46. Jak pokazuje przywoływana już Tomoko Masuzawa, pojęcie to, wraz z fundującą je ramą teoretyczną XIX-wiecznego religioznawstwa, ugruntuje konceptualny związek między tym, co islamskie i tym, co żydowskie. Tym razem kluczem do tego związku będzie pojęcie semickości ${ }^{47}$.

42 J. Le Goff Inteligencja w wiekach średnich, Czytelnik, Warszawa 1966, s. 61.

G. Anidjar Semites. Race, Religion, Literature, s. 58. Tamże, s. 61.

Zob. P. O'Brien European perceptions of Islam and America..., zwł. rozdz. 4 Lingering Asian Superiority (1453-1776). Zob. także K. Pomeranz The Great Divergence: China, Europe, and the Making of the Modern World Economy, Princeton University Press, Princeton 2000; A. Gunder Frank Reorient: Global Economy in the Asian Age, University of California Press, Berkeley 1998. Na temat nowoczesnej kategorii religii i jej związków z europejską dominacją zob. np. mój tekst Religia i rasa. Trajektorie antysemityzmu i islamofobii, w: „Tematy z Szewskiej” $2014 \mathrm{nr} 3$ (13).

Zob. T. Masuzawa Islam, a Semitic Religion, w: The Invention of World Religions. Or, How European Universalism Was Preserved in the Language of Pluralism, The University of Chicago, Chicago 2005. 


\section{"Semici" - znak niższości, znak szlachectwa}

Kategoria „Semitów” była kolejnym, tym razem nowoczesnym i oświeceniowym, wariantem łączenia tego, co żydowskie i tego, co muzułmańskie. Pojawienie się tej kategorii stało się jednak możliwe dopiero wtedy, gdy w teatrze relacji chrześcijańsko-muzułmańskich po raz kolejny zmienili się bohaterowie reprezentujący typowego muzułmańskiego wroga. Kluczową datą jest tutaj rok 1683 i nieudane oblężenie Wiednia, które wyznacza zmierzch kulturowej i militarnej supremacji Imperium Otomańskiego. Wydarzenia te zapoczątkowują nową równowagę sił między „światem islamu” $i$ „światem chrześcijańskim” oraz sprawiają, że „Turcy” przestają dla tego drugiego stanowić zagrożenie i są stopniowo zastępowani w zachodnich wyobrażeniach Orientu i islamu przez Arabów. Dopiero ta zmiana umożliwia narodziny „Semitów” jako kategorii łączącej żydów i muzułmanów na bazie powiązanych czynników językowych, „rasowych” i religijnych. $\mathrm{Z}$ racji odmienności języka tureckiego takie połączenie nie byłoby bowiem możliwe w czasie, gdy synonimem muzułmanina był „Turek". Kalmar i Penslar sugerują w tym kontekście, że proces konstruowania "Araba" jako paradygmatycznej figury muzułmanina mógł być zresztą spowodowany XIX-wiecznym europejskim zainteresowaniem żydowskością - a tym samym „semickością" - i stanowić jego swoisty produkt uboczny. Faktem jest, że od XIX wieku to Arabowie zaczynają w europejskich wyobrażeniach - na powrót, w nowej odsłonie - coraz częściej funkcjonować jako synonim tego, co muzułmańskie.

Jak pisałam wcześniej, kategoria „Semitów” narodziła się w powiązaniu z pojęciami indoeuropejskiej grupy językowej oraz „rasy aryjskiej”, która miała obejmować ludy posługujące się językami z tej grupy. Te lingwistyczno-rasologiczne kategoryzacje były częścią dyskursu, który zasadniczo służył artykułowaniu wyższości cywilizacyjnej Aryjczyków, a dokładniej mieszkańców północnej Europy. Dyskurs ten miał jednak warianty, które akceptując urasowione pojęcie semickości, romantyzowały ją i przypisywały jej rozmaite mityczne wartości kojarzone z domniemanym duchowym bogactwem orientu, $\mathrm{w}$ tym także islamu. Ten sposób rozumienia semickości był zresztą rozwijany przez część intelektualistów żydowskich w XIX-wiecznej Europie, zwłaszcza tych, których zainteresowania wpisywały się w szeroko rozumiany obszar studiów orientalistycznych. Przywołuję go tutaj, ponieważ stanowi on przykład stanowiska podkreślającego integralne więzi między tym, co żydowskie i tym, co muzułmańskie, które jednak nie było stanowiskiem apologetów chrześcijańskiej odrębności i supremacji, ale przyjmowane 
było przez żydowskich myślicieli chcących tę supremację zakwestionować. W tym kontekście istotny jest fakt, że badania orientalistyczne rozwijane przez wspomnianych myślicieli różniły się znacząco od opisywanego przez Edwarda Saida orientalizmu Brytyjczyków i Francuzów, który stanowił integralną część kolonialnego dyskursu legitymizującego ich imperialne panowanie na terenach pozaeuropejskich. Jak pokazuje John M. Efron, większość żydowskich orientalistów należała do niemieckiego obszaru kulturowego i pochodziła z krajów, które nie miały kolonii na Bliskim Wschodzie czy w Maghrebie. Jednak głównym powodem, dla którego charakterystyczną cechą ich orientalizmu była głęboka fascynacja orientem i szacunek, a czasem utożsamienie z islamem, było to, że jako Żydzi, a więc mniejszość dyskryminowana w Europie z powodów religijnych i rasowych, nie mogli się oni zidentyfikować się z dyskursami afirmującymi białą, europejską i zarazem chrześcijańską supremację. Nie mogąc włączyć się w europejską misję cywilizacyjną, żydowscy intelektualiści stworzyli własną odmianę orientalizmu, która odzwierciedlała ich poszukiwanie korzeni i autentyczności. Jak stwierdza Efron, orientalizm ten był „wyrazem [ich] własnych niepokojów i niepewności kulturowej” i wiązał się z „głęboko zakorzenionym strachem przed niższością"48.

Orientalistycznie zorientowane poszukiwanie żydowskich korzeni wyrażało się w tym, że jego zwolennicy „zaakceptowali jako znak honoru pejoratywne oświeceniowe określenie judaizmu jako «orientalnego» ... [i] z atencją podjęli studia nad islamem i/lub żydowską kulturą, która rozkwitła pod jego egidą, z nadzieją, że wielkość i piękno obu może ożywić judaizm i osłabić «dominację i władzę», której sami doświadczali ze strony Europejczyków" "49. Spośród najważniejszych żydowskich orientalistów należy wymienić Abrahama Geigera, Heinricha Graetza czy Ignaza Goldzihera. Wspólnym motywem ich pisarstwa jest próba odnowienia judaizmu i pokazania jego teologicznej i etycznej wyższości nad chrześcijaństwem przy jednoczesnym akcentowaniu integralnych więzi między religią żydowską i islamem. Taką postawę ilustruje także np. powieść Benjamina Disraelego zatytułowana Tankred, w której Żydzi i Arabowie przedstawieni są jako rasa wybrana dostępująca bożego objawienia. Wydaje się, że fascynacja tradycją muzułmańską widoczna jest najwyraźniej w pracach Ignaza Goldzihera, który nie porzucając judaizmu,

48 J. M. Efron Orientalism and the Jewish Historical Gaze, w: I. Davidson Kalmar, D.J. Penslar (eds.): Orientalism and the Jews, s. 80.

Tamże, s. 93. 
dokonał głębokiej identyfikacji z islamem i przedstawił go jako filozoficzny wzór dla wszelkich prób reformowania żydowskiego dziedzictwa intelektualnego i duchowego ${ }^{50}$. Abraham Geiger natomiast, akcentując nadrzędność judaizmu wobec chrześcijaństwa i islamu, starał się wykazać wtórność obu tych tradycji wobec religii żydowskiej, odwracając przy tym zresztą klasyczny topos średniowiecznego antysemityzmu, według którego jednym z faktów obciążających Żydów miało być właśnie to, że są oni odpowiedzialni za narodziny islamu i antychrześcijański sojusz z nim".

Chrześcijańska supremacja nie była jednak jedynym przedmiotem krytyki ze strony żydowskich orientalistów. Był nim także obskurantyzm judaizmu ortodoksyjnego, a zwłaszcza to, co postrzegali oni jako zacofanie i prymitywizm Żydów wschodnioeuropejskich. Próbując zaznaczyć swój dystans wobec tej pogardzanej grupy żydów, orientaliści podkreślali np. ciągłość własnej kultury z wyrafinowanym średniowiecznym dziedzictwem żydów sefardyjskich z muzułmańskiej Hiszpanii ${ }^{52}$. Warto zaznaczyć, że orientalistyczne wątki w kulturze europejskich Żydów XIX wieku nie pozostawały w sferze intelektualnych rozważań i dyskursów akademickich. Znalazły one bowiem także wyraz w codziennym życiu wspólnot żydowskich, choćby w architekturze synagog, które były budowane w stylu mauretańskim. Ponurą ironią historii jest to, że te zaakceptowane przez niektórych Żydów dyskursy - orientalizujące ich tożsamość i akcentujące ich dystans wobec chrześcijaństwa - wkrótce posłużyły jako dowód w sprawie ich „obcości" wobec Europy i dostarczyły uzasadnień dla polityki ich wykluczenia i eksterminacji.

50 "Wczułem się w ducha islamu do takiego stopnia, że nabrałem wewnętrznego przekonania, iż sam jestem muzułmaninem, i używając rozsądku odkryłem, że jest to jedyna religia, która, nawet w swojej doktrynalnej czy oficjalnej formie, może usatysfakcjonować umysł filozoficzny. Moim ideałem jest podnieść judaizm na podobny racjonalny poziom. Jak nauczyło mnie doświadczenie, islam jest jedyną religią, w której składniki zabobonu i pogaństwa nie spotykają się z krytyką ze strony racjonalizmu, ale ze strony ortodoksyjnego nauczania", I. Goldziher Tagebuch, (publikacja zredagowana przez Alexandra Scheibera), Brill, Leiden 1978, cyt. za S.L. Gilman Multiculturalism and the Jews, s. 5.

S. Heschel Judaism, Christianity and Islam Prelude of Revisionist Configuration, w: tejże Abraham Geiger and the Jewish Jesus, University of Chicago Press, Chicago 1998, s. 60-61.

Jak pisze Susannah Heschel, ten sposób myślenia był częścią stworzonego przez żydowskich historyków mitu "Złotej Ery” w historii Żydów w Europie, która miała się cechować się szczególną "twórczą symbiozą" między średniowiecznymi żydami i muzułmanami w Hiszpanii, S. Heschel Judaism, Christianity and Islam. Prelude of Revisionist Configuration, s. 61. 


\section{Antagonizm i polaryzacja}

Dla analiz śledzących pokrewieństwa i różnice między europejskimi dyskursami antysemickimi i antyislamskimi kluczowa jest zarówno historia „Semitów" jako kategorii łączącej żydów i Arabów/muzułmanów, jak i jej ostateczny rozpad, który następuje w XX wieku. Jak mówi Kalmar, w wyniku tego rozpadu „Żydzi i muzułmanie mogą być dziś kochani i/lub nienawidzeni osobno" ${ }^{53}$. Powody tego rozpadu są bardzo złożone i wskazują na kolejne przesunięcie znaczeniowe w relacjach między kategoriami religii i rasy, religii i polityki, rasy i etniczności. Przede wszystkim jednak tkwią w przemianach europejskiej historii XIX i XX wieku. Jednym ze skutków ubocznych tych przemian był zanik opisywanej m.in. przez Bernarda Lewisa tradycji „judeo-islamskiej”.

Według Gila Anidjara przejawem rozpadu samej idei semickości jest rozwijający się od XIX wieku dyskurs syjonistyczny, który bazował na ideałach emancypacji i politycznej podmiotowości zaczerpniętych z nowoczesnego, europejskiego imaginarium politycznego. Taka genealogia projektu syjonistycznego sprawiła, że - jak mówi Anidjar - był on próbą „włączenia się do «historii» i wyzwolenia się od odległego Wschodu, zintegrowania się z europejską wspólnotą poprzez zreprodukowanie jej, wyzwolenia się, po pierwsze, od samego judaizmu [...], po drugie, od islamu, i w końcu, wewnętrznie i zewnętrznie, od Arabów" ${ }^{154}$. Autor ma tutaj przede wszystkim na myśli fakt, że syjonizm jako projekt budowania nowoczesnej żydowskiej podmiotowości politycznej zawierał w sobie konieczność uwolnienia się od ciążącego na Żydach brzemienia „orientalności”. To natomiast wymagało wyzwolenia się od orientalizującej kategorii "Semitów” i rozerwania wszelkich więzi z tym, co w ramach tej kategorii symbolizowało inność wobec nowoczesnej (sekularyzującej się) Europy. Oznaczało to zatem konieczność zdystansowania się, wykluczenia i negacji tego, co religijne, muzułmańskie, arabskie, wschodnie ${ }^{55}$.

Kontekstem rozwoju idei syjonistycznych w Europie była zmiana w relacjach między Żydami i muzułmanami na terenach muzułmańskiego Bliskiego

53 I. Davidson Kalmar Anti-Semitism and Islamophobia: the Formation of a Secret, "Human Architecture: Journal of the Sociology of Self-Knowledge", Spring 2009 VII, 2, S. 137. G. Anidjar Semites. Race, Religion, Literature, s. 33. Ilustracją tego ukierunkowania myśli syjonistycznej mogą być słowa wieloletniego przywódcy żydowskiego, Ben Guriona: „Nie chcemy, aby Izraelczycy byli Arabami. Naszym obowiązkiem jest walczyć przeciwko duchowi Lewantu, który rujnuje jednostki i społeczeństwa", A. Raz-Krakotzkin The Zionist Return to the West and the Mizrahi Jewish Perspective, w: I. Davidson Kalmar, D.J. Penslar (eds.) Orientalism and the /ews, s. 173. 
Wschodu. Kluczowy był tutaj fakt, że znaczna część tych terenów została poddana europejskiej kolonizacji (a przynajmniej silnym europejskim wpływom), panujące na nich relacje międzygrupowe w coraz większym stopniu były więc kształtowane przez politykę kolonizatorów. Jednym ze skutków tej polityki był wzrost antagonizmów między mniejszościami chrześcijańskimi i żydowskimi, a także rosnąca wobec nich niechęć muzułmańskiej większości. Jak pokazuje Bernard Lewis, to w tych okolicznościach na Bliskim Wschodzie pojawił się antysemityzm, początkowo przeniesiony z Europy przez konkurujące z Żydami społeczności chrześcijańskie ${ }^{56}$. Nie mając precedensów w historii relacji muzułmańsko-żydowskich, wkrótce rozprzestrzenił się na tym terenie, stając się instrumentem politycznego oporu wobec projektów syjonistycznego osadnictwa w Palestynie. Niechęć muzułmańskiej większości wobec Żydów i chrześcijan wiązała się z kolei z rosnącą pozycją tych grup, które uzyskując polityczne i ekonomiczne wsparcie zagranicznych protektorów, stawały się bazą dla europejskich wpływów w krajach muzułmańskich ${ }^{57}$. Szczególną rolę w procesie antagonizowania Żydów i Arabów odegrała niewątpliwie polityka, jaką dyplomacja Wielkiej Brytanii prowadziła w okresie mandatu, który kraj ten sprawował na Bliskim Wschodzie. Jak pisze Franco Cardini, Brytyjczycy z jednej strony podburzali „Arabów przeciwko Turkom przy pomocy obietnic utworzenia wielkiej, niezależnej ojczyzny arabskiej", z drugiej - deklarowali gotowość utworzenia państwa żydowskiego w Palestynie. W efekcie „Żydzi i Arabowie po I wojnie światowej zaczęli stanowić przedmiot gry będącej poza intencjami i interesami obu stron i znaleźli się w sytuacji konfliktu"58.

Projekt syjonistyczny został ostatecznie zrealizowany w 1948 roku poprzez ustanowienie Izraela jako „nowoczesnego państwa zachodniego na Wschodzie". Oznaczało to m.in. masowy napływ Żydów do Palestyny. Jak zauważa Amnon Raz-Krakotzkin, w tym procesie historycznym tkwi pewien paradoks. Okazuje się bowiem, że to właśnie „exodus Żydów z Europy

56 Jako wydarzenie, które zapoczątkowało upowszechnianie się antysemityzmu na Bliskim Wschodzie, także w społecznościach muzułmańskich, wymienia się często tzw. sprawę z Damaszku z 1840 roku, w której z inicjatywy lokalnych chrześcijan grupa prominentnych żydów została fałszywie oskarżona o morderstwo chrześcijańskiego mnicha, uwięziona i poddana torturom. W efekcie część z nich zmarła. Sprawa odbiła się szerokim echem wśród diaspory żydowskiej w Europie i Stanach Zjednoczonych. Jak pokazuje Lewis, inspiratorem całej sprawy był konsul francuski. Zob. B. Lewis The Jews of Islam, s. 156, 162.

Tamże, s. 185.

58 F. Cardini Europa a islam: historia nieporozumienia, s. 207. 
umożliwił ich asymilację do Europy, bez potrzeby konwersji"59. Powodem tego exodusu było uznanie, że asymilacja Żydów do europejskich wspólnot narodowych jest niemożliwa i/lub niepożądana, jego efektem natomiast stała się - paradoksalnie - asymilacja Żydów do narracji zachodniego oświecenia. Według Raz-Krakotzkina znakiem tego jest fakt, że „żydowska mniejszość zaakceptowała to samo pojęcie historii, które [wcześniej] umożliwiło jej wykluczenie na dwóch różnych poziomach - teologicznym i kolonialnym. W toku osadnictwa wcieliła ona również perspektywę skolonizowanego i kolonizatora - przemianę skolonizowanego i przyjęcie perspektywy kolo-

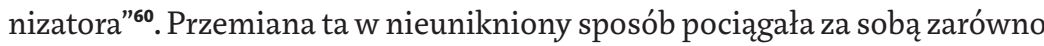
fundamentalną redefinicję relacji między tym, co żydowskie i tym, co europejskie, jak i przekształcenie stosunku między tym, co żydowskie i tym, co arabskie/muzułmańskie.

Wspomniane przekształcenie nie tylko przyczyniło się do rozpadu omawianej kategorii „Semitów”, ale także do radykalnej polaryzacji figury Żyda i Araba, żyda i muzułmanina. W efekcie w dyskursywnym polu wyznaczonym przez nowe sensy tych figur i pojęć pojawiła się nieobecna wcześniej sfera wykluczeń i niewidoczności. Jest to sfera wygnania, swoistej diasporyczności wszelkich tożsamości liminalnych, na różne sposoby oscylujących między żydowskością i arabskością, żydowskością i muzułmańskością. Szczególnie poruszające świadectwo takiej bezdomności daje Ella Habiba Shohat, tematyzująca z osobistej perspektywy doświadczenie żydów mizrahijskich ${ }^{61}$.W swoim tekście Refleksje na temat utraty włosów i pamięci Shohat sięga do historii własnej rodziny, irackich żydów z Bagdadu, która, podobnie jak setki tysięcy żydów zamieszkujących kraje arabskie, po pierwszej wojnie arabsko-izraelskiej w latach 1948-1949 została zmuszona do opuszczenia Iraku i emigracji do nowo utworzonego państwa Izrael. Uciekając przed falą antysemityzmu, aktywowanego w krajach arabskich w wyniku ustanowienia państwa Izrael i rozwoju arabskich idei narodowych, żydzi ci spotkali się w swojej nowej „ojczyźnie” z różnego rodzaju dyskryminacją, której Shohat nie waha się nazwać rasizmem ${ }^{62}$. Jak pisze, „Żydzi z Iraku, Egiptu i Jemenu po

\footnotetext{
59 A. Raz-Krakotzkin A National Colonial Theology: Religion, Orientalism, and Construction of the Secular in Zionist Discourse, w: Ethnizität, Moderne und Enttraditionalisierung, "Tel Aviver Jahrbuch für deutsche Geschichte" 2002 XXX, s. 317.

60 Tamże.

61 E. Habiba Shohat Refleksje na temat utraty włosów i pamięci, "Lewą Nogą” 200214.

62 Tamże, s. 203.
} 
powstaniu Izraela padli ofiarą dwóch krwawych nacjonalizmów: arabskiego i żydowskiego. [...] Chociaż żydzi-Arabowie byli kulturowo, rasowo i językowo bliżsi muzułmanom-Arabom niż Żydom z Europy, którzy zbudowali państwo Izrael, ich tożsamość była na cenzurowanym ze strony obydwu idei narodowych"63. Z jednej strony bowiem w krajach arabskich, w których zamieszkiwali od tysiąca lat, zaczęli być traktowani jako "zdrajcy" i na mocy dekretów państwowych zostali pozbawieni praw i majątku, z drugiej - w samym Izraelu, jako nowoczesnym państwie zachodnim, byli traktowani jako rasowo niżsi reprezentanci zacofanego "orientu" i często postrzegani jako „czarni”. Sytuacja ta, w powiązaniu z ramą kategorialną, która jako nieodwoływanie rozłączne określiła to, co żydowskie i to, co muzułmańskie/arabskie, sprawiła, że hybrydyczność tożsamości żydów mizrahijskich jednocześnie została ujawniona i zdelegitymizowana. Z perspektywy zachodniej stała się bowiem rodzajem „myślnikowej” tożsamości „złożonej”, która mogła już tylko wywoływać „ontologiczne zmieszanie" i automatyczny gest redukcji i unieważnienia składnika ,orientalnego"64.

Na gruncie zachodnim szczególnym przejawem symbolicznej asymilacji żydowskości do tego, co europejskie, jest rozpowszechnienie się po II wojnie światowej pojęcia „dziedzictwa judeochrześcijańskiego" ${ }^{2}$. Podkreślając integralną więź między judaizmem i chrześcijaństwem pojęcie to przeciwstawiło się wcześniejszej antysemickiej tradycji deprecjonowania tego, co żydowskie i definiowania Żydów jako bezapelacyjnie zewnętrznych i wrogich względem tego, co chrześcijańskie, europejskie, zachodnie, cywilizowane. Kluczowym czynnikiem była tutaj tragiczna historia XX wieku i doświadczenie Zagłady, które przeorganizowało etyczno-polityczne fundamenty europejskiej normatywności ${ }^{66}$. Częścią tej reorganizacji była oficjalna delegitymizacja

63 Tamże, s. 207.

64 Tamże, s. 202

65 Zob. S.L. Gilman Multiculturalism and the Jews, s. 5-6; T. Asad Formations of the Secular. Christianity, Islam, Modernity, Stanford University Press, Palo Alto 2003; I. Davidson Kalmar Anti-Semitism and Islamophobia: the Formation of a Secret, s. 135-144.

Pisze o tym Enzo Traverso, który zauważa, że w Europie i Stanach Zjednoczonych „pamięć Holokaustu przeobraziła się w swego rodzaju «religię obywatelską» (tzn. zgodnie z sensem, w jakim rozumiał to Rousseau, w świecką wiarę konieczną dla jedności wspólnoty)". Jak stwierdza, „zrytualizowane... upamiętnianie ludobójstwa dokonanego na Żydach służy sakralizacji wartości konstytutywnych dla liberalnej demokracji: pluralizmu, tolerancji, praw człowieka", E. Traverso Historia jako pole bitwy. Interpretacja przemocy wXX wieku, Książka i Prasa, Warszawa 2014 , S. 310 
antysemickich dyskursów, które zamykały Żydów w nieprzekraczalnych kategoriach religijnej i rasowej odmienności/niższości ${ }^{67}$. Ta symboliczna rewizja pojęcia europejskości i skorelowanego z nią rozumienia tego, co żydowskie - pociagająca za sobą nowy projekt Europy/Zachodu poszerzonych o państwo Izrael i obejmujących Żydów jako ich pełnoprawnych członków - sprawiły, że, jak twierdzi Anidjar, „Żydzi w istocie stali się zachodnimi chrześcijanami"68.

Etyczna, polityczna i kulturowa asymilacja żydowskości do tego, co europejskie/zachodnie, zaowocowała jednak także zmianą w postrzeganiu muzułmanów i Arabów. Według Ivana Davidsona Kalmara, po II wojnie światowej wizerunek Żyda stopniowo uwalnia się od stygmatu demoniczności, jaki cechował zbiorczą kategorię „Semitów”, i zaczyna być łączony z profetycznym wymiarem żydowskiej tradycji. Jednocześnie, jak stwierdza autor,

następuje projekcja demonicznego aspektu wyobrażonej semickości na innego Semitę: Araba i - przez rozszerzenie - muzułmanina. Wydaje się, iż w tym punkcie ... Żydzi uwalniają się od brzemienia semityzmu i antysemityzmu. Arabowie i muzułmanie pozostają jedynymi Semitami, demonizowanymi na takie same sposoby, jak Żydzi przedtem. ${ }^{69}$

\section{Obcość: nowe rozdania}

Historia sposobów, na jakie w europejskim kontekście konstruowano figury żyda i muzułmanina, Żyda i Araba, to historia symbolicznych przesunięć, które wyznaczają wspominaną na początku niebinarną geometrię tożsamości i inności. Wydaje się, że w ostatnich dekadach geometrię tę wyznaczają dwa skorelowane ze sobą procesy. Z jednej strony właśnie w tym czasie intensyfikuje się przepracowywanie antysemickiej przeszłości Europy i następuje rozwój badań nad Holokaustem. Kontekstem jest tu pogłębianie integracji europejskiej, włączanie nowych członków do UE oraz poszukiwanie nowych narracji stabilizujących kruchą europejską jedność. Pamięć Holokaustu i odcinanie się od antysemickiej przeszłości Europy odgrywa wśród tych narracji ważną rolę (choć nie dotyczy to w równym stopniu Europy Wschodniej

67 Zob. D.T. Goldberg Racial Europeanization „ "Ethnic and Racial Studies” March 2006 Vol. 29, No. 2.

68 The /ew, the Arab: An Interview with Gil Anidjar, http://asiasociety.org/countries/religions-philosophies/jew-arab-interview-gil-anidjar (05.03.2014.)

69 I. Davidson Kalmar Anti-Semitism and Islamophobia: the Formation of a Secret, s. 137-138. 
i Zachodniej) ${ }^{70}$. Jednocześnie można zaobserwować wyciszenie motywów antysemickich w dyskursach europejskich partii prawicowych, które swój ksenofobiczny impet zaczynają kierować przeciwko imigranckim mniejszościom, głównie muzułmańskim. Z drugiej strony ostatnie dekady to także czas, w którym dochodzi do radykalnej eksplozji dyskursów o „konflikcie cywilizacji” zachodzącym rzekomo między Zachodem a „światem islamu”. Eksplozji tej towarzyszy coraz silniejsze koncentrowanie się na „muzułmańskości” jako znaku „cywilizacyjnej” obcości rozmaitych grup mniejszościowych w Europie, które wcześniej były identyfikowane (i same się identyfikowały) raczej poprzez różnorodne przynależności etniczne czy narodowe, a nie religijne. Lata 9o., a zwłaszcza początek bieżącego stulecia, są także okresem, w którym rozwija się dyskurs „wojny z terroryzmem”, owocujący kolektywną stygmatyzacją osób kojarzonych z islamem. Tym wewnątrzeuropejskim procesom rekonstruowania stosunku do żyda i muzułmanina, Żyda i Araba, towarzyszy narastający konflikt izraelsko-palestyński (przedstawiany czasem jako konflikt żydowsko-arabski lub żydowsko-muzułmański). Jego główną sceną jest Palestyna, odciska on jednak swoje piętno także na rzeczywistości zachodnich społeczeństw"

Od drugiej połowy XX wieku mamy zatem do czynienia z jednej strony z procesem stopniowego rewidowania wcześniejszych wzorów wrogości wobec Żydów i postępującą akceptacją ich symbolicznej „wewnętrzności” wobec tego, co europejskie czy zachodnie ${ }^{72}$, drugiej - z eskalacją dyskursów

O różnicach, jakie w odniesieniu do polityki kultywowania pamięci o Holokauście występują między krajami Europy Zachodniej i postkomunistycznymi krajami Europy Wschodniej, pisze Enzo Traverso. Jak zauważa, kraje Europy Wschodniej koncentrują się na przedstawianiu siebie jako ofiar XX-wiecznej historii i z tego powodu „pamięć Szoah nie odgrywa [w nich] tej samej wspólnotowej roli jak na Zachodzie”. Jest raczej postrzegana jako "swego rodzaju pamięć konkurencyjna, jako przeszkoda do pełnego uznania cierpień doznanych przez inne wspólnoty narodowe w XX wieku", E. Traverso Historia jako pole bitwy, s. 316.

71 Jeśli chodzi o konsekwencje, jakie konflikt palestyński ma dla relacji między antysemityzmem i islamofobią w Europie, zob. Monika Bobako "The Palestinian Knot: The 'New Anti-Semitism', Islamophobia and the Question of Postcolonial Europe" Theory, Culture and Society, Prepublished May 12, 2017 DOI: 10.1177/0263276417708859

Co nie oznacza, że antysemityzm został skutecznie w Europie zwalczony. Oznacza to tylko, że stracił publiczną legitymizację i jako projekt ideologiczny funkcjonuje na obrzeżach politycznego spektrum, aktywując się głównie poniżej poziomu oficjalnych działań i narracji instytucji, które organizują życie zachodnich społeczeństw. Nie przeczy to temu, że uprzedzenia antysemickie pozostają elementem osobistych przekonań wielu członków europejskich społeczeństw, a także temu, że funkcjonują one często jako kod, w którym wyrażana jest ksenofo- 
akcentujących obcość muzułmanów i Arabów ${ }^{73}$. W tym kontekście zasadne wydaje się stwierdzenie, że Żydzi stają się w Europie coraz mniej „obcy”, natomiast Arabowie i muzułmanie - coraz bardziej. Sytuacja ta prowokuje do postawienia pytania o to, w jaki sposób przedstawiona powyżej rekonfiguracja relacji między różnymi kategoriami „obcych” czy też „innych” Europy wpływa na aktualny sens jej tożsamości. Poszukując odpowiedzi na to pytanie, nie można zapominać, że wszelkie figury obcości mówią zawsze więcej o tych, którzy je tworzą niż o tych, którzy są przez nie oznaczani.

biczna wrogość wobec rozmaitych przejawów "obcości”, nie tylko żydowskiej. Odradzanie się nacjonalistycznych tradycji w ostatnich latach w Polsce pokazuje jednak, że groźba ponownego wprowadzenia dyskursów antysemickich do polityki głównego nurtu jest realna.

73 Jak pokazują statystyki, muzułmanie są przedmiotem niechęci znacznie częściej niż Żydzi. W krajach takich jak USA, Francja czy Niemcy nieprzychylne postawy wobec muzułmanów są mniej więcej dwa razy częstsze niż wobec Żydów (w Polsce i Hiszpanii różnica wynosi tylko kilka punktów procentowych). Unfavorable Views of Jews and Muslims on the Increase in Europe, PEW Global Attitudes Project, Pew Research Center Washington 2008. Streszczenie dostępne na stronie: http://www.pewglobal.org/subjects/islamophobia/ (11.10.2014.) Inne badania, odnoszące się do Wielkiej Brytanii, pokazują, że jedna piąta Brytyjczyków odnosi się negatywnie tylko do muzułmanów, a stosunkowo niewiele osób odczuwa niechęć do jakiejkolwiek innej grupy etnicznej czy religijnej, D. Voas, R. Ling Religion in Britain and the United States, w: British Social Attitudes: The 26th Report, Sage, London 2010, cyt. za N. Meer Semantics, scales and solidarities in the study of antisemitism and Islamophobia, "Ethnic and Racial Studies" 2013 Vol. 36 , No. 3, s. 506. (Tony Kushner dodaje w tym kontekście, że głównymi grupami narażonymi na codzienną przemoc w Wielkiej Brytanii, oprócz muzułmanów, są osoby ubiegające się o azyl, Romowie oraz społeczności prowadzące nomadyczny tryb życia, T. Kushner Anti-Semitism in Britain: continuity and the absence of a resurgence?, "Ethnic and Racial Studies" 2013 Vol. 36, No. 3, s. 445.) Badania francuskie pokazują z kolei, że osoby wywodzące swoje pochodzenie z Maghrebu są we Francji najczęstszymi ofiarami rasistowskich ataków (rasistowska przemoc $-68 \%$, rasistowskie groźby $-60 \%$ ), przy czym najbardziej dla nich niebezpiecznym obszarem jest Paryż i jego okolice, La lutte contre racisme, l'antisémitisme, et la xénophobie: année 2007, Comission Nationale Consultative des Droits de l'Homme 2008, cyt. za R. Taras 'Islamophobia never stands still': race, religion, and culture, "Ethnic and Racial Studies" 2013 Vol. 36, No. 3, 429. 
Abstract

\section{Monika Bobako}

ADAM MICKIEWICZ UNIVERSITY (POZNAŃ)

The Jew and the Arab/Muslim in Europe's Geometries of Identity and Difference

In the European (Christian/secular) imaginary, what are the integral - though sometimes contradictory and hidden - ties that connect Jews and Muslims or Arabs? To account for the constitution of any identity or community we must go beyond the standard analysis that focuses on how identity is formed in relation to what is other. Bobako argues that in the case of European (Christian/secular) communities and identities, a key element in the relation to 'otherness' is a conceptual and political juggling of various categories of 'others,' such as the figures of the 'Jew' and the 'Muslim' or 'Arab'. She reconstructs the shifting configurations in which these figures have appeared throughout European history. These configurations have evolved, from the stage when ideas about Jews and Muslims or Arabs often contained different notions of their kinship and closeness, until the stage marked by a radical symbolic and political break between what is seen as Jewish and what is seen as Muslim or Arab. Bobako thus contributes to laying the groundwork for a better understanding of the mechanisms of anti-Semitism and Islamophobia as well as their mutual correlations.

\section{Keywords}

Jew, Arab, Muslim, Semite, Islam, Islamophobia, anti-Semitism 